\title{
The Influence of Self Control and Economic Literacy on Student Lifestyle (at Madrasah Aliyah Islamiyah Ciputat)
}

\author{
Kharisma Danang Yuangga ${ }^{1}$, Jasmani ${ }^{2}$ \\ 1.2 Universitas Pamulang \\ E-mail: danangyuangga@gmail.com
}

(Received: December-2017; Reviewed: January-2018; Accepted: February-2018;

Avalaibel Online: February-2018; Published: March-2018)

(7) (8) This is an open access article distributed under the Creative Commons Attribution License CC-BY-NC-4.0 @2018 by author (https://creativecommons.org/licenses/by-nc/4.0/)

\begin{abstract}
Consumptive behavior carried out at adolescence is more likely to be impulsive and sudden. The purpose of this study was to determine the effect of self-control and economic literacy on students' lifestyles on the MA Islamiyah Ciputat. The method used is descriptive method with an associative approach. The sampling technique used was proportional random sampling using a sample of 75 respondents. The analysis tool uses validity test, reliability test, classic assumption test, regression analysis, correlation coefficient analysis, coefficient of determination analysis and hypothesis testing. The results of this study are self-control and a significant positive effect on student lifestyle by $40.7 \%$. Hypothesis testing is obtained $t_{\text {count }}>t_{\text {table }}$ or $(7.082>1.993)$, so that $\mathrm{H} 0$ is rejected and $\mathrm{H} 1$ is accepted, meaning that there is a positive and significant influence between self-control of students' lifestyles at the Ciputat MA Islamic Office. Economic literacy has a positive and significant effect on student lifestyle by $36.2 \%$. Hypothesis testing is obtained $t_{\text {count }}>t_{\text {table }}$ or $(6.438>1.993)$ so that $H 0$ is rejected and $\mathrm{H} 2$ is accepted meaning that there is a positive and significant influence between economic literacy on students' lifestyles. A simultaneous test of self-control and economic literacy has a positive and significant effect on students' lifestyles with a contribution of $48.4 \%$, while the remaining $50.3 \%$ is influenced by other factors. Hypothesis testing obtained the value of $F_{\text {count }}>F_{\text {table }}$ or $(36.384>2.730)$, thus Ho is rejected and $\mathrm{H} 3$ is accepted. This means that there is a positive and significant effect simultaneously between self-control and economic literacy on the lifestyle of students at MA Islamiyah Ciputat.
\end{abstract}

Keywords: Self-control; economic literacy; student lifestyle.

\section{INTRODUCTION}

Teenage age is a complex phase in human life (Ali Mohammad, 2010; Anisa, 2017; Elida \& Remaja, 1991). In this age range, people are faced with the first problems in life, experiencing new things as a form of self-development and forms of adaptation to the environment that is full of dynamics. Consumptive behavior is the behavior of someone who does not lag based on rational considerations, materialistic tendencies, a great desire to have the luxury and excessive objects and uses everything that is considered the most expensive and 
driven by all desires to fulfill the desires of pleasure solely (Anggreini \& Mariyanti, 2014; Dewi, Rusdarti, \& Sunarto, 2017; Mawo, Thomas, \& Sunarto, 2017; Wahyudi, 2013). Conducting consumption activities is not based on necessity reasons, but for other reasons such as following trends, curiosity due to new output products, wanting to gain popularity, selfcontrol is needed so that consumptive behavior can be controlled more carefully and measured. Consumptive behavior carried out at adolescence is more likely to be impulsive and sudden (Astuti, 2013; Dikria \& W., 2013; Miranda, Sofia dan Lubis, 2017). The things that indicate consumers behave consumptively are because they buy the product because the packaging is very attractive; buying products because of the lure of gifts; buy products to maintain the appearance of self and prestige; buy products based on price (not the basis of benefits and usefulness); buy products because of the status symbol; use the product because of the conformity elements of the advertising model; the emergence of self-image that buying products at high prices will lead to high confidence; use more two similar products due to different brands (Sumartono, 2002)

Lifestyle can be defined as a way for someone to live, that includes how someone spends his money, how he uses his time and so on (Risnawati, Mintarti, \& Wardoyo, 2018; Solihat \& Arnasik, 2018; Sunarsi, 2016). According to (Kotler dan Amstrong, 2008) lifestyle is a person's lifestyle that is expressed in his activities, interests, and opinions, in other words, lifestyle can be seen from the routine activities he does, what they think about everything around him and how far he cares about himself and the outside world.

The lifestyle of MA Islamiyah Ciputat students, very dynamic, can change very quickly. This change is a form of adaptation to the environment. Changes that occur in general are not caused by changes in needs, in adolescence (puberty) parents are no longer role models (role models), but the same people who are the main models (Fudyartanta, 2012). This causes students to imitate the behavior carried out by their surroundings, especially peers. In a gathering that is often done by adolescents, the tendency to share many things is huge, one of which is a lifestyle.

Economic literacy is a useful tool for changing behavior from not intelligent to intelligent. As utilizing income to save, invest, protect and meet the necessities of life (Kanserina, 2015; Krishna, Rofaida, \& Sari, 2010; Maulita \& Mersa, 2017). The importance of economic literacy will minimize the consumptive behavior of students in consumption. Low economic literacy will cause consumptive attitudes and this understanding is very necessary (Herawati, Candiasa, Yadnyana, \& Suharsono, 2018; Muhammad Hasan, 2017; Welly, Kardinal, \& Juwita, 2012). MA Islamiyah Ciputat is a secondary school located in Ciputat. The majority of students have problems with self-control in consumption. Understanding of economic literacy is also quite low so as to bring up consumptive behavior in everyday lifestyles. This has become one of their factors for being consumptive in their teens.

\section{METHOD}

The type of data used is quantitative with primary data sources by distributing questionnaires which are then tabulated and feasibility analysis and secondary data derived from the various scientific literature. The population in this study were MA Islamiyah Ciputat students, totaling 295 students. Sampling was used by the (Hidayat, 2017) formula technique with an error rate of $10 \%$ to obtain a sample of 73 students. The instrument testing uses validity and reliability tests. From the validity and reliability test stated valid and reliable, this is evidenced by the value of $r_{\text {count }}>r_{\text {table }}$, likewise, the instrument used is appropriate and feasible to be forwarded to the next test. 


\section{RESULT AND DISCUSSION}

MA Islamiyah Ciputat is a secondary school located in Ciputat. The majority of students have problems with self-control in consumption. Understanding of economic literacy is also quite low so as to bring up consumptive behavior in everyday lifestyles. This has become one of their factors for being consumptive in their teens

\section{Descriptive Analysis}

Table 1.

Descriptive Statistics

\begin{tabular}{lr|r|r|r|r} 
& N & Minimum & Maximum & Mean & Std. Deviation \\
\hline Self Control (X1) & 75 & 32 & 47 & 38.24 & 3.719 \\
\hline Economic Literacy (X2) & 75 & 30 & 49 & 38.81 & 4.441 \\
\hline Student Lifestyle (Y) & 75 & 31 & 46 & 39.21 & 3.610 \\
\hline Valid N (listwise) & 75 & & & & \\
\hline
\end{tabular}

The self-control data obtained a minimum variance score of 32 and a maximum score of 47 and a ratting mean score of 38.24 and a standard deviation level of 3.719. Economic literacy data obtained results of a minimum variance score of 30 and a maximum score of 49 and a ratting mean score of 38.81 and a standard deviation level of 4.441. Lifestyle data of students obtained results of a minimum variance score of 31 and a maximum score of 46 and a ratting mean score of 39.32 and a standard deviation level of 3.605.

\section{Verification Analysis}

Verification analysis is intended to determine the magnitude of the influence and analyze the significance of the influence. In this analysis carried out on the influence of two independent variables on the dependent variable. partially or simultaneously

This multiple regression test is intended to find out how much influence the variables X1 and $\mathrm{X} 2$ have on the $\mathrm{Y}$ variable. In this study self-control (X1) and economic literacy (X2) on students' lifestyles $(\mathrm{Y})$. The following are the results of processed regression data with SPSS version 26 which can be seen in the following table:

Table 2.

Results of Multiple Regression Processing Variables Self-Control (X1) and Economic Literacy (X2) on Student Lifestyle (Y)

\begin{tabular}{|c|c|c|c|c|c|c|}
\hline \multicolumn{7}{|c|}{ Coefficients $^{\mathrm{a}}$} \\
\hline \multirow{2}{*}{\multicolumn{2}{|c|}{ Model }} & \multicolumn{2}{|c|}{$\begin{array}{l}\text { Unstandardized } \\
\text { Coefficients }\end{array}$} & \multirow{2}{*}{$\begin{array}{c}\text { Standardized } \\
\text { Coefficients } \\
\text { Beta }\end{array}$} & \multirow[b]{2}{*}{$\mathrm{t}$} & \multirow[b]{2}{*}{ Sig. } \\
\hline & & $\mathrm{B}$ & Std. Error & & & \\
\hline 1 & (Constant) & 11.236 & 3.307 & & 3.397 & .001 \\
\hline & Self ControlX1) & .430 & .095 & .443 & 4.510 & .000 \\
\hline & Economic Literacy(X2) & .297 & .080 & .365 & 3.716 & .000 \\
\hline
\end{tabular}

a. Dependent Variable: Student Lifestyle(Y) 
Based on the results of the regression calculation in the above table, the regression equation $\mathrm{Y}=11.236+0.430 \mathrm{X} 1+0.297 \mathrm{X} 2$ can be obtained. A constant value of 11,236 means that if the variables Self-control (X1) and economic literacy (X2) are absent, there is already a student lifestyle (Y) of 11,236 points. The value of 0.430 is interpreted if the constant is constant and there is no change in the economic literacy variable (X2), then every 1 unit change in the selfcontrol variable (X1) will result in a change in student lifestyle (Y) of 0.430 points. The value of 0.297 is interpreted if the constant is constant and there is no change in the Self Control variable (X1), then every 1 unit change in the economic literacy variable (X2) will result in a change in the lifestyle of students (Y) of 0.297 points.

Analysis of the coefficient of determination is intended to determine the percentage of the contribution of influence between the independent variables on the dependent variable both partially and simultaneously), in this study the variables of self-control (X1) and economic literacy (X2) on student lifestyle (Y). Here are the results of the calculation of the coefficient of determination, as follows:

Table 3

Partial Results of Analysis of the Coefficient of Determination Between Self-Control (X1) Against Student Lifestyle (Y)

\begin{tabular}{lcc|c|c|c} 
& \multicolumn{4}{c}{ Model Summary } & \\
Model & $\mathrm{R}$ & & R Square & $\begin{array}{c}\text { Adjusted } \\
\text { R Square }\end{array}$ & $\begin{array}{c}\text { Std. Error of the } \\
\text { Estimate }\end{array}$ \\
\hline 1 & $.638^{\mathrm{a}}$ & .407 & .399 & 2.799 \\
\hline
\end{tabular}

a. Predictors: (ConstantSelf-Control (X1)

Based on the test results in the table above, an R-Square value or determination of 0.407 is obtained, this shows that the contribution of influence between self-control to students' lifestyles is $40.7 \%$, while the remaining $59.3 \%$ is influenced by other factors not examined.

Table 4.

Partial Results of Analysis of the Coefficient of Determination Between Economic Literacy (X2) Against Student Lifestyle (Y)

\begin{tabular}{|c|c|c|c|c|}
\hline \multicolumn{5}{|c|}{ Model Summary } \\
\hline Model & $\mathrm{R}$ & R Square & $\begin{array}{l}\text { Adjusted R } \\
\text { Square }\end{array}$ & $\begin{array}{l}\text { Std. Error of } \\
\text { the Estimate }\end{array}$ \\
\hline 1 & $.602^{\mathrm{a}}$ & .362 & .353 & 2.903 \\
\hline
\end{tabular}

a. Predictors: (Constant), Economic Literacy (X2)

Based on the test results in the table above, an R-Square value or determination of 0.362 is obtained, this shows that the contribution of the influence of economic literacy to student lifestyle is $36.2 \%$, while the remaining $63.8 \%$ is influenced by other factors not examined. 
Table 5.

Simultaneous Determination Coefficient Analysis Results Between Self-Control (X1) and Economic Literacy (X2) Against Student Lifestyle (Y)

\begin{tabular}{l|c|c|c|c} 
& \multicolumn{4}{c}{ Model Summary } \\
Model & $\mathrm{R}$ & R Square & $\begin{array}{c}\text { Adjusted R } \\
\text { Square }\end{array}$ & $\begin{array}{c}\text { Std. Error of the } \\
\text { Estimate }\end{array}$ \\
\hline 1 & $.709^{\mathrm{a}}$ & .503 & .489 & 2.581 \\
\hline a. Predictors: (Constant), Economic Literacy (X2), Self-Control (X1)
\end{tabular}

Based on the test results in the table above, the R-Square value or determination of 0.503 is obtained, this shows that the contribution of the effect between self-control and economic literacy simultaneously on student lifestyles is $50.3 \%$, while the remaining $49.7 \%$ is influenced by other factors not examined.

To test the hypotheses of self-control variables (X1) and economic literacy (X2) on students' lifestyles (Y), the statistical test $t$ (partial test) was conducted.

Table 6.

The results of data processing using SPSS version 26, with the following results:

T-Test Results for Self Control Variables (X1)

\section{Coefficients $^{a}$}

\begin{tabular}{|c|c|c|c|c|c|c|}
\hline \multirow{2}{*}{\multicolumn{2}{|c|}{ Model }} & \multicolumn{2}{|c|}{$\begin{array}{l}\text { Unstandardized } \\
\text { Coefficients }\end{array}$} & \multirow{2}{*}{$\begin{array}{c}\text { Standardized } \\
\text { Coefficients } \\
\text { Beta } \\
\end{array}$} & & \multirow[b]{2}{*}{ Sig. } \\
\hline & & B & Std. Error & & & \\
\hline & (Constant) & 15.524 & 3.360 & & 4.620 & .000 \\
\hline & Kontrol Diri (X1) & .619 & .087 & .638 & 7.082 & .000 \\
\hline
\end{tabular}

a. Dependent Variable: Student Life Style $(\mathrm{Y})$

Based on the test results in the above table, the value of $t_{\text {count }}>t_{\text {table }}$ or $(7.082>1.993)$ is also strengthened by the value of $\rho$ value $<$ Sig. 0.05 or $(0,000<0.05)$. Thus, $\mathrm{H} 0$ is rejected and $\mathrm{H} 1$ is accepted, this shows that there is a positive and partially significant effect between self-control on students' lifestyles

Table 7.

T-Test

\begin{tabular}{|c|c|c|c|c|c|}
\hline \multirow[b]{3}{*}{ Model } & \multicolumn{3}{|c|}{ Coefficients $^{a}$} & \multirow[b]{3}{*}{$\mathrm{t}$} & \multirow[b]{3}{*}{ Sig. } \\
\hline & \multicolumn{2}{|c|}{$\begin{array}{l}\text { Unstandardized } \\
\text { Coefficients }\end{array}$} & \multirow{2}{*}{$\begin{array}{l}\text { Standardized } \\
\text { Coefficients } \\
\text { Beta }\end{array}$} & & \\
\hline & $B$ & Std. Error & & & \\
\hline 1 (Constant) & 20.224 & 2.969 & & 6.813 & .000 \\
\hline Literasi Ekonomi (X2) & .489 & .076 & .602 & 6.438 & .000 \\
\hline
\end{tabular}

a. Dependent Variable: Student Life Style (Y)

Based on the test results in the table above we get the value of $t_{\text {count }}>t_{\text {table }}$ or $(6.438>1.993)$, it is also strengthened by $\rho$ value $<$ Sig. 0.05 or $(0,000<0.05)$. Thus, H0 is rejected and H2 is accepted, this shows that there is a positive and partially significant effect between economic literacy on students' lifestyles.

To test the effect of variable self-control and economic literacy simultaneously on the lifestyle of students on the Ciputat Islamic MA is carried out with a statistical test $\mathrm{F}$ (simultaneous test) with a significance of $5 \%$. 


\begin{tabular}{|c|c|c|c|c|c|c|}
\hline \multicolumn{7}{|c|}{ ANOVA $^{a}$} \\
\hline \multicolumn{2}{|c|}{ Model } & $\begin{array}{l}\text { Sum of } \\
\text { Squares }\end{array}$ & $d f$ & Mean Square & $\mathrm{F}$ & Sig. \\
\hline \multirow[t]{3}{*}{1} & Regression & 484.850 & 2 & 242.425 & 36.384 & $.000^{\mathrm{b}}$ \\
\hline & Residual & 479.736 & 72 & 6.663 & & \\
\hline & Total & 964.587 & 74 & & & \\
\hline
\end{tabular}

a. Dependent Variable: Student Life Style (Y)

b. Predictors: (Constant), Economic Literacy $(\mathrm{X} 2)$, Self-Control(X1)

Based on the test results in the above table, the calculated $F_{\text {count }}>F_{\text {table }}$ or $(36.384>2.730)$ is also strengthened by the $\rho$ value $<$ Sig. 0.05 or $(0,000<0.05)$. Thus, H0 is rejected and H3 is accepted, this shows that there is a positive and significant effect simultaneously between self-control and economic literacy on the lifestyle of MA Islamiyah Ciputat students.

\section{CONCLUSION}

Based on the results of the study, economic literacy has a positive and significant effect on students' lifestyles with a magnitude of influence of $36.2 \%$. Hypothesis testing obtained t count> $t$ table or (6.438> 1.993). Self-control and economic literacy have a positive and significant effect on students' lifestyles with a regression equation $\mathrm{Y}=11.236+0.430 \mathrm{X} 1+0.297 \mathrm{X} 2$. The higher self-control and economic literacy, the lifestyle of students will also increase. The amount of influence is $50.3 \%$ while the remaining $49.7 \%$ is influenced by other factors. Hypothesis testing obtained the value of $F_{\text {count }}>F_{\text {table }}$ or $(36.384>2.730)$, it is also strengthened with a probability of $0,000<0.05$. Self-control has a positive and significant influence on students' lifestyles with a magnitude of influence of $40.7 \%$. Hypothesis testing obtained $t_{\text {count }}>t$ table or $(7.082>1.993)$

\section{REFERENCES}

Ali Mohammad, M. A. (2010). Psikologi Remaja Perkembangan Peserta Didik. Psikologi Remaja Perkembangan Peserta Didik.

Anggreini, R., \& Mariyanti, S. (2014). Hubungan Antara Kontrol Diri Dan Perilaku Konsumtif. Jurnal Psikologi.

Anisa, R. N. (2017). Psikologi Remaja Perkembangan Peserta Didik. psikologi.

Astuti, E. D. (2013). Perilaku Konsumtif dalam Membeli Barang pada Ibu Rumah Tangga di Kota Samarinda. eJournal Psikologi.

Dewi, N., Rusdarti, \& Sunarto, S. (2017). Pengaruh Lingkungan Keluarga , Teman Sebaya , Pengendalian Diri dan Literasi Keuangan Terhadap Perilaku Konsumtif Mahasiswa. Jee. https://doi.org/ISSN : 2301-7341

Dikria, O., \& W., S. U. M. (2013). Pengaruh Literasi Keuangan dan Pengendalian Diri Terhadap Perilaku Konsumtif Mahasiswa Jurusan Ekonomi Pembangunan Fakultas Ekonomi Universitas Negeri Malang Angkatan 2013. Pengaruh Literasi Keuangan dan Pengendalian Diri Terhadap Perilaku Konsumtif Mahasiswa Jurusan Ekonomi Pembangunan Fakultas Ekonomi Universitas Negeri Malang Angkatan 2013.

Elida, P., \& Remaja, P. P. (1991). Perkembangan Peserta Didik. Dirjen Dikti: Jakarta.

Fudyartanta. (2012). Psikologi Kepribadian. Yogyakarta: Pustaka Pelajar. 
Herawati, N. T., Candiasa, I. M., Yadnyana, I. K., \& Suharsono, N. (2018). Pengaruh Kualitas Pembelajaran Keuangan dan Literasi Keuangan Terhadap Financial Self Efficacy Mahasiswa Akuntansi. JPEKA: Jurnal Pendidikan Ekonomi, Manajemen dan Keuangan. https://doi.org/10.26740/jpeka.v2n2.p115-128

Hidayat, A. (2017). Cara Hitung Rumus Slovin Besar Sampel.

Kanserina, D. (2015). Pengaruh Literasi Ekonomi dan Gaya hidup Terhadap Perilaku Konsumtif Mahasiswa Jurusan Pendidikan Ekonomi Undiksha 2015. Pengaruh Literasi Ekonomi dan Gaya Hidup Terhadap Perilaku Konsumtif Mahasiswa Jurusan Pendidikan Ekonomi Undiksha 2015.

Kotler dan Amstrong. (2008). Prinsip-Prinsip Pemasaran Jilid I. In Erlangga.

Krishna, A., Rofaida, R., \& Sari, M. (2010). Analisis Tingkat Literasi Keuangan(Survey pada Mahasiswa Universitas Pendidikan Indonesia). Proceedings of The 4th International Conference on Teacher Education; Join Conference UPI \& UPSI Bandung, Indonesia.

Maulita, \& Mersa, N. A. (2017). Pengaruh Literasi Keuangan Terhadap Pengelolaan Keuangan Pribadi Pada Mahasiswa di Politeknik Negeri Samarinda. Seminar Nasional Inovasi Teknologi Terapan.

Mawo, T., Thomas, P., \& Sunarto, S. (2017). Pengaruh Literasi Keuangan, Konsep Diri dan Budaya Terhadap Perilaku Konsumtif Siswa Sman 1 Kota Bajawa. Journal of Economic Education.

Miranda, Sofia dan Lubis, E. E. (2017). Pengaruh Instagram Sebagai Media Online Shopping Fashion Terhadap Perilaku Konsumtif Mahasiswi Fakultas Ilmu Sosial Dan Ilmu Politik Universitas Riau. Jurnal Online Mahasiswa Fisip.

Muhammad Hasan. (2017). Pendidikan Ekonomi Informal dan Literasi Keuangan. Membangun Indonesia Melalui Riset.

Risnawati, Mintarti, S. U., \& Wardoyo, C. (2018). Pengaruh Pendidikan Ekonomi Keluarga , Gaya Hidup , Modernitas Individu, dan Literasi Ekonomi terhadap Perilaku Konsumtif Siswa. Jurnal Pendidikan.

Solihat, N. A., \& Arnasik, S. (2018). Pengaruh Literasi Ekonomi Dan Gaya Hidup Terhadap Perilaku Konsumtif Mahasiswi Pendidikan Ekonomi Universitas Siliwangi. Oikos : Jurnal Kajian Pendidikan Ekonomi dan Ilmu Ekonomi.

Sumartono. (2002). Terperangkap dalam Iklan: Meneropong Imbas Pesan Iklan Televisi. Bandung: Alfa Beta.

Sunarsi, D. (2016). Hubungan Pengendalian Diri dengan Prestasi Belajar. Penelitian. Fakultas Ekonomi Universitas Pamulang.

Wahyudi. (2013). Tinjauan Tentang Perilaku Konsumtif Remaja Pengunjung Mall Samarinda Central Plaza. eJournal Sosiologi.

Welly, Kardinal, \& Juwita, R. (2012). Analisis Pengaruh Literasi Keuangan Terhadap Keputusan Investasi Di STIE Multi Data Palembang. Jurnal Ilmu Ekonomi. 
130 Pinisi Discretion Review

Volume 1, Issue 2, March, 2018. Pages 123-130 